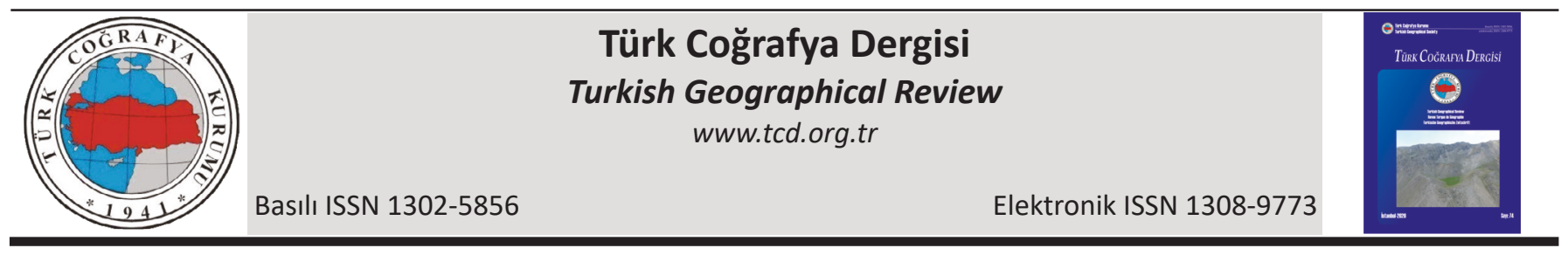

\title{
İstanbul'un sosyal konut üretim alanlarından biri: Tuzla
}

\author{
One of the social housing production areas of Istanbul: Tuzla
}

\author{
Ömer Bozdoğan*a (D) Hüsniye Doldur ${ }^{b}$ \\ aistanbul Üniversitesi, Sosyal Bilimler Enstitüsü, Coğrafya Anabilim Dalı, i̇stanbul. \\ ${ }^{b}$ Istanbul Üniversitesi, Edebiyat Fakültesi, Coğrafya Bölümü, Istanbul. \\ ORCID: H.D. 0000-0002-3984-7298
}

\section{BILGi / INFO}

Geliş/Received: 11.05 .2020

Kabul/Accepted: 19.06 .2020

\section{Anahtar Kelimeler:}

Sosyal konut

Türkiye

TOKi

İstanbul

Tuzla

\section{Keywords:}

Social housing

Turkey

Tokı

Istanbul

Tuzla

*Sorumlu yazar/Corresponding author:

(O. Bozdoğan) o.bozdogan@gmail.com

DOI: $10.17211 /$ tcd. 735646

\section{Atif/Citation:}

Bozdoğan, Ö. ve Doldur, H. (2020). İstanbul'un sosyal konut üretim alanlarından biri: Tuzla. Türk Coğrafya Dergisi (74), 135 142.

DOI:10.17211/tcd.735646

\begin{abstract}
ÖZ / ABSTRACT
Konut sorunu, kırsal alanlardan şehirlere olan göçün yarattığı en temel sorunlardan biri olmuştur. Dünya genelinde şehirleşmenin yaygınlaşmasıyla daha büyük boyutlara varan bu sorunun çözümü için devletler çeşitli yöntemler geliştirmişlerdir. Geliştirilen yöntemlerden birisi de yoksul ve dar gelirli kesimleri konut sahibi yapmayı amaçlayan sosyal konut uygulamalarıdır. illk olarak 19. yüzyılın sonlarında Avrupa'da başlayan bu uygulamalar, sonraki yıllarda diğer gelişmiş ülkelerde, 20. yüzyılın son çeyreğinden itibaren ise gelişmekte olan ülkelerde görülmeye başlanmıştır. Gelişmekte olan ülkeler kategorisinde yer alan Türkiye'deki ilk sosyal konut uygulamaları 1960'lı yıllarda başlamıştır. 1984 yılında ise Toplu Konut İdaresi'nin (TOKI) kurulması ve 2000'li yıllarda kurumun yetkilerinin genişletilmesiyle sosyal konut çalışmaları günümüze kadar sürdürülmüştür. Türkiye'deki sosyal konut üretimine TOKI dışında KIPTAŞ (İstanbul) ve PORTAŞ (Ankara) gibi bazı belediye kuruluşları da katkı sağlamışlardır. Çalışmada 5000'den fazla sosyal konuta sahip Tuzla İlçesindeki sosyal konut uygulamaları incelenmiştir. Bu uygulamaların Tuzla'da gerçekleştirilme nedenleri ve bu uygulamalar sonrasında mekânsal görünümde ortaya çıkan değişiklikler ele alınmıştır. Çalışmadaki temel veri kaynaklarını kamu kuruluşlarının hazırladığı rapor ve istatistikler yanında arazi çalışmaları, basılı ve görsel kaynaklar ve sosyal konut kullanıcılarıyla yapılan anketler oluşturmaktadır. Ayrıca haritanın hazırlanmasında ArcGIS 10.7 programı kullanılmıştır.
\end{abstract}

The housing problem has been one of the major problems of migration from rural areas to cities. This problem has reached a larger dimension with the spread of urbanization around the world, in order to solve this problem governmentes have developed various methods. One of the methods developed as a solution was social housing practices which are aiming to make poor and low-income people homeowner. Social housing practices first began in Europe in the late 19th century, following years its spread the other developed countries. Developing countries have begun social housing policies last quarter of the 20th century. Turkey as one of the developing countries has started social housing policies 1960s. With the establishment of Public Housing Administration (TOKI) in 1984 and expanding authorizations of institution in 2000s, social housing practices have continued to today. Apart from the TOKI activities, municipality institutions such as KIPTAS (Istanbul) and PORTAS (Ankara) have also contributed to social housing production in Turkey. In this study, social housing practices in Tuzla district, which has more than 5000 social housings have been examined. The reasons why Tuzla district has chosen for this practices and what is the social and spatial consequence of these practices discussed. The main data sources in the study are reports and statistics prepared by public institutions, field studies, printed and visual resources and surveys with social housing users. Also, ArcGIS 10.7 used in the preparation of the map.

\section{Giriş}

Kırsal alanlardan şehirlere olan göçün getirdiği en temel sorunlardan biri konut yetersizliği olmuştur. Bu sorun sanayi faaliyetlerinin yaygınlaşmasıyla daha da büyük boyutlara erişmiştir. Sanayi faaliyetleri yarattkları iş olanaklarıyla kırsal alanlardaki nüfusu adeta mıknatıs gibi kendilerine çekerek bulundukları şehirlerin nüfuslarının çok hızlı ve kontrolsüz büyümesine neden olmuştur (Tümertekin ve Özgüç, 2015). Bu durum şehirlerde başta konut olmak üzere pek çok sorunun ortaya çıkmasını sağlamıştır. Kırdan şehre olan bu göç hareketi, şehirlerde konuta olan talebi arttırarak konut fiyatları ve kiralarının yükselmesine neden olmuştur. Kırdan şehre iş bulmak amacıyla gelenler ise yüksek konut fiyatları karşısında kendi inşa ettikleri derme çatma konutlarla (gecekondularla) barınma ihtiyaçlarını gidermek zorunda kalmışlardır. Sanayinin yaygınlaşması, şehirlere 
olan göçü hızlandırarak bu elverişsiz konutlardan yararlananIarın sayısını arttırmıştır. Böylece şehirlerde altyapısı yetersiz, işsizliğin ve suç oranlarının yüksek olduğu gecekondu mahalleleri (slum) ortaya çıkmıştır (Pacione, 2005). Şehirlerdeki bu elverişsiz barınma alanlarının sürekli olarak genişlemesi salgınlar ve yoksullukla bağlantılı çeşitli sosyal sorunların da ortaya çıkmasına neden olmuştur. Bu sorunların zamanla artması ve şehrin tamamını tehdit eder hale gelmesiyle, devletler sorunları çözmek için harekete geçmek zorunda kalmışlardır. Bu amaçla geliştirilen yöntemlerden birisi de yoksul ve dar gelirli nüfusa sağlıklı yaşam alanları sunmayı amaçlayan sosyal konut uygulamaları olmuştur (Greenhalgh ve Moss, 2009).

Sosyal konut uygulamaları, yoksul ve dar gelirli grupların devlet tarafindan çeşitli şekillerde (kamu destekli konut sübvansiyonlarının sağlanması, kamu konutlarının düşük fiyatlardan kiraya verilmesi ve düşük faizli ve uzun vadeli konut kredilerinin sağlanması gibi) desteklenerek barınma sorununu çözmeyi amaçlayan uygulamalar olarak geliştirilmişlerdir. Ayrıca kaçak yapılaşmayı önleyerek planlı şehirleşmeyi sağlama, kentsel altyapıyı güçlendirme ve bireyler arası sosyal ilişkilerin geliştirilmesine katkı sağlama gibi diğer avantajlarıyla da benimsenerek yaygınlaştııımışlardır (Oxley, 2009).

\section{Veri ve Yöntem}

Makalede İstanbul'un Anadolu yakasındaki ilçesi Tuzla'daki sosyal konut uygulamaları incelenerek, Tuzla'nın sosyal konut üretimi için sahip olduğu potansiyel değerlendirilmiştir. Çalışma kapsamında ulusal ve uluslararası literatür taranmış, çeşitli kamu kuruluşlarının hazırladığı istatistiklerden yararlanılmıştır. Ayrıca coğrafyanın çalışma alanını oluşturan mekânsal ilişkiler çerçevesinde, Tuzla'da arazi çalışmaları ve sosyal konut kullanıcılarıyla anketler yapılarak elde edilen veriler harita, tablo ve fotoğraflarla görsel olarak da sunulmuştur. Haritanın hazırlanmasında ArcGIS 10.7 programı kullanılmıştır.

\section{Bulgular}

\subsection{Dünya'da Sosyal Konut Politikaları ve Gelişim Süreci}

Dünya genelinde uygulanan sosyal konut politikalarını üç dönem içerisinde ele almak mümkündür. Bunlardan ilki sanayileşmenin başlangıcından II. Dünya Savaşı'na kadar olan süreci kapsamaktadır (Kunduracı, 2013). Bu dönemde, sanayileşme faaliyetlerine önce başlayan gelişmiş Avrupalı ülkeler konut sorununu ilk yaşayan ülkeler olmuş ve sorunun çözümü için ilk sosyal konut çalışmaları da bu ülkelerde (1889'da Belçika'da, 1890 'da İngiltere'de, 1894'te Fransa'da ve 1901'de Hollanda'da) hayata geçirilmiştir (Wassenberg, Vroelant ve Reinprecht, 2008). Bu dönemdeki sosyal konut faaliyetleri merkezi yönetimler, yerel yönetimler (belediyeler) ve kamu destekli konut kooperatifleri öncülüğünde gerçekleştirilmiştir. Doğrudan sosyal konut üretiminin yanı sıra gecekondu dönüşüm projeleriyle de sosyal konutlar üretilmiştir. Üretilen sosyal konutlar ise yoksul ve dar gelirlilere piyasa koşullarından daha düşük fiyatlarda kiralık konut şeklinde sunulmuştur.

Sanayi faaliyetlerine ilk başlayan Ingiltere'de sanayi, 1800'lü yıllar boyunca kırsal alanlardan nüfusu şehirlere çekmiş ve şehirlerin nüfuslarının katlanarak artmasına neden olmuştur. Bu yıllarda Londra 900.000'den fazla nüfusuyla dünyanın en büyük şehri durumundaydı. Ülkenin diğer şehirlerinde de nüfus hızla artmıştır. 1801 yılında 75.000 nüfuslu bir şehir olan Manchester'ın nüfusu 1851 'de 338.000 'e yükselmiştir. Aynı süreç içerisinde Birmingham'ın nüfusu da 71.000'den 265.000'e çıkarak \%273'lük bir artş göstermiştir (Pacione, 2005). Bu artan nüfusun konut ihtiyacını karşılamak üzere belediyelerin geliştirdikleri sosyal konut politikaları önem kazanmış ve 1900 yılında Londra'nın Bethnal Green bölgesinde sosyal konut alanındaki ilk büyük proje hayata geçirilmiştir. Bu sosyal konut projesiyle gecekondu mahallelerinde yaşayan 5700 kişi yeni konutlara taşınarak yer değiştirmiştir (Greenhalgh ve Moss, 2009). Birinci Dünya Savaşı'nın sona ermesiyle gerek savaştan dönen birliklerin konut ihtiyacının karşılanması gerekse de sosyal kalkınmayı gerçekleştirmek amaçlarıyla İngiltere'de sosyal konut yatırımları hız kazanmıştır. Bu dönemdeki sosyal konut uygulamalarıyla İngiltere'de sosyal konutların sayısı 1 milyonu geçmiş ve toplam konut stoku içerisinde sosyal konutların oranı \%10'a ulaşmıştır (Malpass ve Murie, 1999).

19.yüzyılın sonlarında sosyal konut çalışmalarına başlayan bir diğer ülke Fransa olmuştur. Fransa'da da kırsal alanlardan şehirlere olan göçler ve Birinci Dünya Savaşı'nın getirmiş olduğu yıkım sosyal konutların yapılmasını zorunlu kılmıştır. Bu dönemde Fransa'daki sosyal konut uygulamaları ingiltere'nin aksine yerel yönetimler tarafindan değil de, Société française des habitation à bon marché (HBM) isimli ucuz konut yapımından sorumlu konut kuruluşları tarafindan gerçekleştirilmiştir. Devlet bu kuruluşlara vergi muafiyetleri ve kredi avantajları sağlayarak destek olmuştur (Olgun, 2014).

Bu dönemde Amerika Birleşik Devletleri'nde (ABD) sosyal konut uygulamaları Avrupa'dakilerden farklı bir seyir izlemiştir. Avrupalı ülkelerin sosyal konut üretmine başladığı bu dönemde, ABD'de yoksul ve dar gelirlilere yönelik sosyal konut üretimleri yerine New York ve Boston gibi şehirlerde konut kooperatifleri tarafindan yüksek gelirliler için lüks konutlar üretilmiştir (Stone, 2003). ABD'de sosyal konutların ihtiyaca dönüşmesi 1929 ekonomik krizinden sonra olmuştur. Kriz sonrasında işsizliğin artması ve vatandaşların gelirlerinin düşmesi sonucunda halk yoksullaşarak şehirlerdeki konut masraflarını karşılayamaz hale gelmiştir. 1930'ı yılların bu sancılı süreci ABD'de kalıcı bir konut programı oluşturulmasını zorunlu kılmıştır (Kunduracı, 2013). Bu çerçevede kamu kaynaklarının düşük gelirli ailelerin ihtiyacı olan sosyal konutların yapımında kullanılması politikaları desteklenmiş ve 1936 yılında Atlanta'da ilk sosyal konut projesi hayata geçirilmiştir. Bir nevi gecekondu dönüşüm uygulaması olan bu projeyle, gecekondu mahallelerindeki eski konutlar yıkılarak yerine yeni konutlar yapılmış ve proje kapsamında 1600 dar gelirli aileye konut sağlanmıştır (Gournay, 1993).

Sosyal konut politikalarında ikinci dönem ise II. Dünya Savaşı'ndan 1980'lere kadar olan süreci kapsamaktadır (Kunduracı, 2013). Savaşın getirdiği tahribat sosyal ve şehirsel düzenlemeleri gerekli kılmış, harabeye dönen şehirlerin imarı ve konut sorunu savaştan çıkan ülkeler için öncelikli olarak çözülmesi gereken sorunların başında gelmiştir. Buna ek olarak savaş sonrası süreçte batılı ülkelerin hızla sanayileşme çabaları şehirlere olan göçü tetikleyerek konut sorununun daha büyük boyutlara ulaşmasına yol açmıştır. 
Savaş ortamının getirmiş olduğu olumsuz koşullar, devletleri sosyal politikalara yönlendirmiş ve sosyal devlet anlayışının gereği olarak sosyal konut politikaları önem kazanmıştır. Bu politikalar eşliğinde batılı gelişmiş ülkelerde sosyal konut üretimlerine ayrılan kaynaklar arttırılmış ve sosyal konut uygulamaları çıkarılan kanunlarla da desteklenmiştir. Bu doğrultuda hükümetler, yerel yönetimlere ve konut kuruluşlarına maddi desteklerde bulunmuş, konut sübvansiyonları sağlamış, krediler vermiş ve bu kredilere düşük faizler uygulayarak sosyal konut üretimlerini desteklemiştir (Pittini ve Laino, 2011). Bütün bu çalışmalar neticesinde bu dönemde Avrupa'da sosyal konutların sayısı ve toplam konut stokları içerisindeki oranları en üst düzeye ulaşmıştır.

1970'li yıllara gelindiğinde ise 1973 ve 1979 ekonomik krizlerinin de etkisiyle devletler, kamu harcamalarını azaltmaya yönelik politikalar izleyerek konut sektöründen kademeli olarak çekilmeyi amaçlamışlardır. Ayrıca önceki dönemde yapılan konutların eskimesi, (bu konutların yenilenmesi için büyük maddi kaynak gereksinimi) ve Fransa ve $A B D$ gibi ülkelerde sosyal konut bölgelerinde sosyal ayrımcılığın ve marjinalleşmenin başlaması gibi temel sebeplerle devlet ve hükümetler sosyal konut uygulamalarından çekilmeye yönelik politikalar izlemeye başlamıştir. Bunun sonucunda sosyal konut üretimleri azalmış ve kiralık sosyal konut üretimleri yerine vatandaşların kendi konutlarına sahip olması politikaları benimsenmiştir (Wassenberg vd., 2008).

Üçüncü dönem ise 1980 lerden günümüze kadar olan süreci kapsamaktadır. 1980 sonrası dönemde ekonomik krizler, gelişmiş ülkelerdeki demografik değişimler (nüfus artış hızının yavaşlaması ve nüfusun yaşlanmaya başlaması gibi) ve neoliberal politikalar (devletlerin özelleştirmeler yoluyla kamu hizmetlerinden geri çekilmeye başlaması) ile birlikte gelişmiş ülkelerde sosyal konut politikalarının önemi azalmaya başlamıştır. Buna karşılık gelişmekte olan dünyada ise sanayileşme ve hızlı şehirleşme süreciyle bağlantılı olarak ilk defa sosyal konut uygulamaları hayata geçirilmiştir (Kunduracı, 2013). Gelişmekte olan ülkelerde 1950'li yıllardan sonra tarımda makineleşmenin başlaması, kırsal alanlardaki iş olanaklarının sınırlı kalması ve şehirlerin sanayileşmesi gibi sebeplerle kırsal alanlardan şehirlere ve özellikle büyük şehirlere yoğun bir göç yaşanmıştı. Şehirlere yığılan bu nüfus, konut talebinde artş̧a neden olmuş, şehirlerde zaten sınırlı olan konut stoku ise talebi karşılayamayarak konut sorununa dönüşmüştür. Hâlihazırda iş bulma amacıyla şehirlere gelenler ise maddi olarak iyi durumda olmadıkları için konut bulma konusunda sıkınt çekmiş ve bu süreçte kendi konutlarını inşa etme yoluna gitmişlerdir. Bu imarsız ve iskânsız kendi konutunu inşa etme süreci dünya genelinde ve özellikle gelişmekte olan ülkelerin büyük şehirlerinde yoksulluğun ve nüfus hareketlerinin getirdiği gecekondu sorununu ortaya çıkarmıştır. Gecekondu alanlarında konut sorunlarına ek olarak diğer sosyal sorunların da görülmesi devletlerin sosyal konut politikalarına bu ülkelerde de yönelmesini zorunlu kılmıştır. Böylece gelişmekte olan ülkelerde de 1980'li yıllardan sonra sosyal konut uygulamaları yaygınlaşmaya başlamıştır.

\subsection{Türkiye'de Sosyal Konut Politikaları ve Gelişimi}

Gelişmekte olan ülkeler grubunda yer alan Türkiye'de 1950'li yıllarda sanayi faaliyetlerinin yaygınlaşmaya başlamasıyla kırsal alanlardan şehirlere olan göç hareketi hızlanmış, bu durum şehirlerde konut sorununun ortaya çıkmasına neden olmuştur. İlk olarak İstanbul ve Ankara gibi büyük şehirlerde ortaya çıkan sorunun çözümü için 1958'de İmar ve İskân Bakanlığı kurulmuştur (Tekeli, 1996). 1960'lı yıllarda ise sosyal devlet olmanın gerekleri doğrultusunda gelir seviyesi düşük vatandaşların konut ihtiyacını karşılamak üzere sosyal konut üretimine yönelik kararlar kalkınma planlarında (I. II. ve III. Kalkınma Planı) yer almıştir. Ancak planlanan hedefler doğrultusunda yeterli konut üretimi gerçekleştirilememiştir (DPT, 1963). Bunun üzerine şehirlere gelenler kendi olanaklarıyla derme çatma inşa ettikleri konutlarla barınma ihtiyaçlarını gidermeye çalışmışlardır. Bu durum da şehirlerde imarsız ve iskânsız gecekondu bölgelerinin ortaya çıkmasına neden olmuştur (Bayraktar, 2006).

1980 sonrası dönemde şehirleşmenin daha da hızlanmasına bağlı olarak gecekondu sorunu daha büyük boyutlara ulaşmıştr. Sorunun giderek büyümesi, devleti harekete geçirmiş ve 1984 yılında konut sorununa kamusal çözüm üretmek amacıyla Toplu Konut İdaresi (TOKi) kurulmuştur. TOKi, kamu arsalarında piyasa koşullarında konut sahibi olmak için yeterli maddi güce sahip olmayan kişilere, uzun vadede ödeme kolaylıklarıyla sosyal konutlar üretmekte ve bu konutları mortgage modeliyle satş̧a sunmaktadır. Konut uygulamaları hayata geçirilirken konutla birlikte diğer altyapı hizmetleri de tamamlanmaktadır (TOKi, 2010). İdare, kurulduğu ilk yıllarda doğrudan konut üretiminin yanı sıra, konut kooperatiflerine krediler sağlayarak kooperatiflerin sayı ve etkinliklerini arttırmıştır. İlerleyen yıllarda ise ekonomik krizler nedeniyle fon kaynaklarındaki kesintiler ve kooperatiflerdeki bozulmaların da etkisiyle TOKi kooperatiflere krediler vermek yerine konut üretimini kendi gerçekleştirme politikalarına ağırlık vermiştir (Çoban, 2012).

2000 sonrası dönemde ise oluşturulan Acil Eylem Planı'yla (T.C. 58. Hükümet Acil Eylem Planı, 2003) konut seferberliği ilan edilerek gecekondulaşmanın önlenmesi, var olan gecekonduların yenilenmesi ve yetersiz olan konut stokunun arttırılması hedeflenmiştir. Bu hedefleri gerçekleştirmek için TOKi'nin yetkileri arttırılmış, böylece TOKi ülke genelinde konut üretiminin finansör ve uygulayıcısı konumuna getirilmiştir (T.C. 58. Hükümet Acil Eylem Planı, 2003). Bu uygulamalar rakamlara da yansımıştır öyle ki kuruluşundan 2002 yılına kadar olan süreçte yalnızca 43.145 konut inşa eden TOKi, 2002'den 2017'ye kadar olan süreçte yaklaşık 800.000 konutun inşasını gerçekleştirmiştir (TOKI, 2017).

Tablo 1. TOKi tarafindan inşa edilen konutlar (2002-2017) . Table 1. Houses builded by TOKI (2002-2017).

\begin{tabular}{|l|l|l|}
\hline UYGULAMA & KONUT SAYISI & YÜZDE (\%) \\
\hline Dar ve Orta Gelir Grubu & 336.081 & 44,00 \\
\hline Alt-Yoksul Gelir Grubu & 149.702 & 19,60 \\
\hline Gecekondu Dönüşüm & 125.214 & 16,39 \\
\hline Afet Konutu Uygulaması & 37.734 & 4,94 \\
\hline Tarım Köy Uygulaması & 5.747 & 0,75 \\
\hline $\begin{array}{l}\text { TOPLAM SOSYAL } \\
\text { KONUT }\end{array}$ & $\mathbf{6 5 4 . 4 7 8}$ & $\mathbf{8 5 , 6 8}$ \\
\hline DİĞER UYGULAMALAR & 117.758 & 14,32 \\
\hline GENEL TOPLAM & $\mathbf{7 7 2 . 2 3 6}$ & $\mathbf{1 0 0}$ \\
\hline
\end{tabular}

Kaynak: TOKi, 2017 
TOKI, Planlı Kentleşme ve Konut Üretimi Seferberliği kapsamında 2002 yılından 2017 yılına kadar toplam 772.236 konutun üretimini tamamlamıştır. Bu konutların \% 85,68'ini (654.478 konut) sosyal konutlar oluşturmaktadır. Toplam 654.478 sosyal konutun 336.081'i Dar ve Orta Gelir Gruplar için, 149.702'si AltYoksul Gelirli Grupları için yapılırken üretilen konutların 125.214'ünü ise gecekondu dönüşüm kapsamındaki konutlar oluşturmuştur. Tablo 1'de de görüldüğü üzere TOKI'nin ürettiği konutların yalnızca \%19,6'sı alt gelir gurubuna yöneliktir. Orta gelirlilere yönelik üretilen konutlar ise \%44'lük oranla öne çıkmaktadır (Tablo 1).

Türkiye'de TOKI dışında sosyal konut üretimine İstanbul KiPTAŞ ve Ankara PORTAŞ gibi belediye kuruluşları da katkı sağlamışlardır. Çarpık şehirleşmenin önlenmesi ve dar gelirli vatandaşların konut sahibi olabilmesini amaçlayan bu kuruluşlar, konut inşası yanında altyapı ve sosyal donat alanlarının inşa faaliyetlerini de gerçekleştirmişlerdir.

\subsection{Tuzla'da Sosyal Konut Uygulamaları}

Türkiye'nin en gelişmiş ve en çok göç alan şehri olan İstanbul, göçün neden olduğu pek çok sorunla karşı karşıya kalmaktadır. Bu sorunların en önemlilerinden biri de konut sorunudur. 1980 sonrası dönemde hız kazanan göç hareketi, İstanbul'da imarsız ve iskânsız gecekondu tipi yapılaşmanın yaygınlaşmasına neden olmuştur. Sonraki yıllarda göçün devam etmesi, bir yandan şehirdeki gecekondu bölgelerinin yaygınlaşmasına, diğer yandan da bu bölgelerde sosyal sorunların (işsizlik, çevre kirliliği, suç oranlarının artması vb.) artmasına neden olmuştur. Bu gecekondu bölgelerinde yaşayanların konut sorunlarını çözmek ve daha sağlıklı bir çevrede yaşamalarını sağlamak amaçlarıyla sosyal konut uygulamaları hayata geçirilmiştir. İstanbul'daki ilk sosyal konut uygulamaları İmar ve İskân Bakanlığı tarafindan Zeytinburnu, Sağmalcılar (Bayrampaşa) ve Osmaniye Mahallesinde (Bakırköy) gerçekleştirilmiştir (Tekeli, 1996). Daha sonra bu uygulamalar Başakşehir, Küçükçekmece, Pendik ve Tuzla gibi ilçelerde daha büyük ve kapsamlı olarak hayata geçirilmiştir.

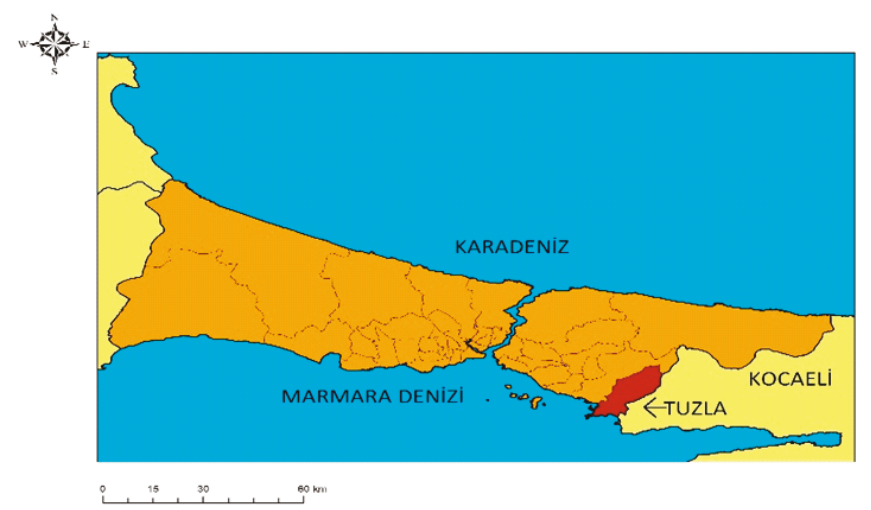

Şekil 1. Tuzla'nın konumu

Figure 1. Location of Tuzla

İstanbul Anadolu Yakası'nda yer alan Tuzla, 2000 yılından sonra İstanbul'un sosyal konut uygulamalarıyla dikkat çeken ilçesi olmuştur (Şekil:1). Doğusunda Gebze ve Çayırova (Kocaeli), kuzey ve batıda Pendik, güneyde ise 13 km. kıyı uzunluğuyla Marmara Denizi ile çevrili olan Tuzla'nın güneydeki uç noktasını ise Marmara Denizi'nde büyük bir çıkınt yaparak uzanan Tuzla Burnu oluşturmaktadır.

Cumhuriyet'in ilk yıllarında Kocaeli Vilayeti, Gebze Bucağı'na bağlı olan Tuzla, 1954'te İstanbul'a bağlanmıştır. Önce Kartal daha sonra Pendik ilçeleri sınırları içinde yer alan Tuzla, 1991'de Pendik'ten ayrılarak müstakil ilçe statüsü kazanmıştır.

Tuzla'da sosyal konut üretim süreci ilçenin gelişimiyle paralellik göstermektedir. Tuzla'daki mekânsal değişim ve dönüşüm 1980 sonrası dönemde tersanelerin Tuzla'ya taşınmasıyla başlamıştır. Tersaneler yarattkları iş olanaklarıyla civar bölgelerden nüfusun Tuzla'ya göç etmesine neden olmuştur (Doğaner, 1993). Tuzla'da nüfus artışını sağlayan önemli gelişmelerden biri de 1990'lı yılların başında TEM Otoyolu'nun Tuzla'dan geçmesi olmuştur. Aynı yıllarda İstanbul'un merkezi kesimlerindeki sanayi faaliyetlerinin şehrin dışına çıkarılması yönündeki politikaların da uygulamaya konulması, TEM Otoyolu güzergâhı üzerindeki konumu ve sahip olduğu boş ve uygun fiyatlı arsaları ile Tuzla'yı önemli bir cazibe merkezi haline getirmiştir. Böylece Tuzla, İstanbul'un merkezi kesimlerinde yer alan sanayi faaliyetlerinin taşınacağı en ideal alanlardan bir haline gelmiştir. Nitekim 1992'de İstanbul Kazlıçeşme'de yer alan deri fabrikaları, Tuzla'da (Aydınlı Mahallesi'nde) oluşturulan Deri Organize Sanayi Bölgesi'ne taşınmıştır. Sonraki yıllarda Tuzla'nın değişik bölgelerinde İstanbul Anadolu Yakası Organize Sanayi Bölgesi, Tuzla Organize Sanayi Bölgesi, Deri Organize Sanayi Bölgesi, Birlik Organize Sanayi Bölgesi ve Tuzla Kimya Sanayicileri Organize Sanayi Bölgesi gibi çeşitli alanlarda (mermer, plastik, kimya, makine) faaliyet gösteren sanayi bölgeleri kurulmuştur (Doğan, 2013).

Bütün bu gelişmeler Tuzla'yı İstanbul'un önemli sanayi alanlarından biri haline getirmiştir. Tuzla'da oluşturulan organize sanayi bölgeleri kısa süre içinde bölgenin sosyal ve ekonomik yaşamında olduğu kadar mekânsal kullanımında da değişimlere neden olmuştur. Önceleri tarım ve hayvancılık faaliyetlerinin egemen olduğu bölge, bir sanayi bölgesi haline gelmiştir (Bozdoğan, 2019). Sanayi tesislerinin yarattğı iş olanakları ise Tuzla'ya olan göçü hızlandırarak 1980 öncesinde yaklaşık 15 bin olan nüfusun, 1990 'larda 100 bine yaklaşmasına ve günümüzde de 255 binin üzerine çıkmasına neden olmuştur (Tablo 2 ).

Tablo 2. Yıllara Göre Tuzla'nın Nüfusu

Table 2. Population of Tuzla by Years

\begin{tabular}{|l|l|}
\hline YIL & NÜFUS \\
\hline 1950 & 3065 \\
\hline 1960 & 4393 \\
\hline 1970 & 9905 \\
\hline 1980 & 16.440 \\
\hline 1990 & 96.150 \\
\hline 2000 & 123.225 \\
\hline 2010 & 185.219 \\
\hline 2018 & 255.468 \\
\hline
\end{tabular}

Kaynak: http://www.tuik.gov.tr/Start.do 
Hızlı sanayileşmeye paralel olarak gerçekleşen nüfus yığılması, Tuzla'da mekânsal kullanımda hızlı değişimler yaratmıştır. Hızla artan nüfusun, konut sorununa aynı hızda çözümler üretilemeyince sanayi faaliyetlerinde çalışmak üzere bölgeye gelenler, kendi imkânlarıyla altyapı olanaklarından yoksun olarak inşa ettikleri konutlarla gecekondu mahallelerinin (Aydıntepe, Aydınlı, Şifa ve Mimar Sinan Mahalleleri) oluşmasına neden olmuşlardır. Bu mahallelerde yıllar içinde ulaşım, su, çöp, trafik ve kanalizasyon gibi çeşitli problemlerin ortaya çıkması üzerine çözüm olarak, bu bölgeleri rehabilite etmeyi amaçlayan sosyal konut uygulamaları hayata geçirilmiştir.

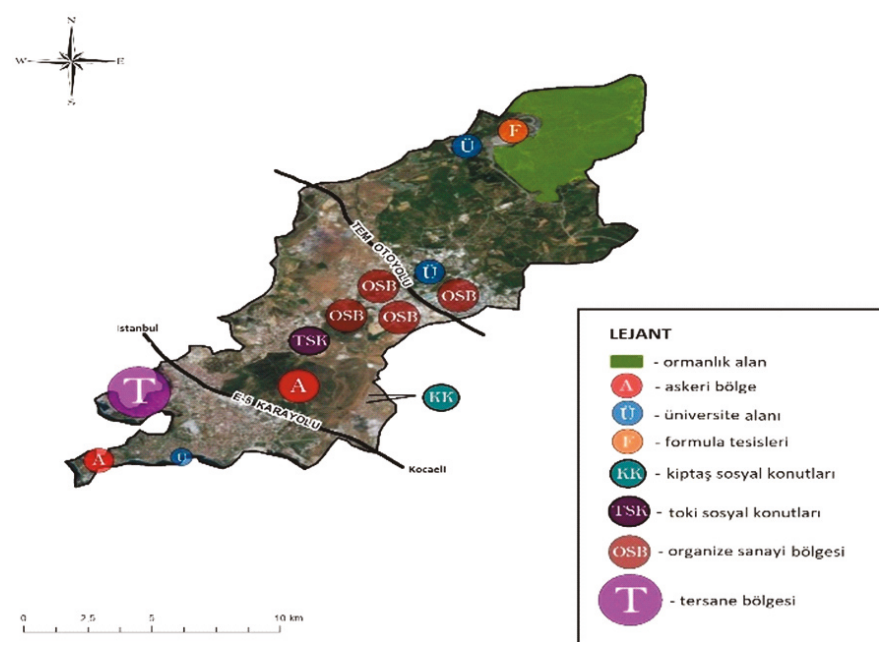

Şekil 2. Tuzla'nın mekânsal kullanımı

Figure 2. Land use map in Tuzla district

Sosyal konut uygulamalarının Tuzla'da gerçekleştirilmesinin çeşitli nedenleri bulunmaktadır: Bunlardan ilki Tuzla'nın bir sanayi bölgesi olması sebebiyle hızla artan nüfusunun konut ihtiyacını planlı kentleşme perspektifiyle (bölgedeki gecekondu mahallelerini rehabilite etmeyi amaçlayan gecekondu dönüşüm projelerinin uygulanması) karşılama ihtiyacıdır. ikincisi, Tuzla'daki şehirleşme hareketlerinin İstanbul'un diğer ilçelerine göre daha geç başlaması nedeniyle ilçenin büyük ölçekli konut projelerinin gerçekleştirilmesine olanak sağlayacak geniş, boş arsalara sahip olması ve üçüncü olarak yine Tuzla'nın İstanbul'un diğer ilçelerine göre daha geç gelişen bölgelerinden biri olması nedeniyle bölgede arsa bedellerinin düşük olmasıdır. ${ }^{1}$ Sosyal konut üretimi için Tuzla'nın sahip olduğu bu avantajlar 2000'li yıllardan itibaren TOKI ve KIPTAŞ² gibi kuruluşlar tarafindan değerlendirilmiş ve Tuzla, İstanbul'un sosyal konut üretim alanlarından biri olmuştur (Şekil 2). Bu iki kuruluş da bölgede sosyal konut uygulamaları gerçekleştirmişlerdir (Tablo 3). Tuzla'da ilk sosyal konut uygulamasını KiPTAŞ, Birinci Etap Konutları Projesiyle gerçekleştirmiştir (Bozdoğan, 2019).

2006 yılında kaçak yapılaşmanın yoğun olduğu Şifa Mahallesi'nde başlatılan bu proje 2 yıl içerisinde tamamlanmıştır. 75, 95, 125 ve $138 \mathrm{~m}^{2}$ gibi dört farklı daire seçeneğiyle toplam 1332

${ }^{1}$ Bilindiği gibi sosyal konut üreticisi kamu kuruluşları yalnızca sosyal konut üretmemekte üst gelir grubu için lüks konutlar da üretmektedirler. İşte bu konut üreticisi kamu kuruluşları lüks konutları daha değerli araziler üzerinde gerçekleştirirken sosyal konut uygulamalarını ise Tuzla gibi arsa fiyatlarının daha makul olduğu ilçelerde gerçekleştirmektedirler.

2 İstanbul Büyükşehir Belediyesi'nin kuruluşu olan KiPTAŞ, çarpık şehirleşmenin önlenmesi ve kaçak yapılaşmanın engellenmesi amaçlarıyla konut inşa etmek üzere 1987 'de kurulmuştur. Konutla birlikte altyapı ve sosyal donatı alanlarının inşa faaliyetlerini de gerçekleştirmektedir. dairenin yer aldığı projede ayrıca yeşil alanlar, çocuk oyun alanları, spor alanları ve çardak gibi sosyal etkinlik alanlarına da yer verilmiştir (Fotoğraf 1).

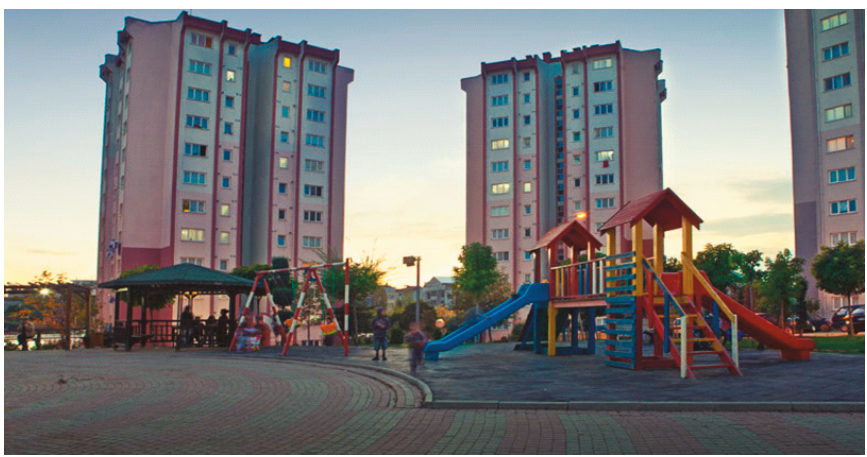

Fotoğraf 1. Kiptaş Tuzla 1.Etap Sosyal Konutları'ndan Bir Görünüm Photo 1. View from Tuzla Kiptaş Social Housing Project

KIPTAŞ'ın Tuzla'da sosyal konut kapsamında gerçekleştirmiş olduğu projelerinden ikincisi ise Tuzla İkinci Etap Konutları'dır. Kiptaş'ın her aile ev sahibi olsun sloganıyla 2007'de Mimar Sinan Mahallesi'nde başlattğı proje 2009'da tamamlanmıştir. 75,95 ve $115 \mathrm{~m}^{2}$ olmak üzere 3 farklı tipte toplam 1728 dairenin yer aldığı projede, yeşil alanlar, çocuk oyun alanları ve sosyalkültürel etkinlik alanları yer almaktadır. Kiptaş'ın sosyal konut projeleri kapsamında Tuzla'da gerçekleştirdiği son proje ise, Tuzla İkinci Etap projesiyle aynı site alanı içerisinde inşa edilen Tuzla Üçüncü Etap Konutları'dır. Kiptaş'ın diğer iki sosyal konut projesine kıyasla bu projede sadece 260 daire yer almış ve konutların tamamı $95 \mathrm{~m}^{2}$ olarak inşa edilmiştir.

Tablo 3. Gerçekleştiren kuruma göre Tuzla'daki sosyal konut inşaatları

Table 3. Socail housing unit in Tuzla completed by institutions

\begin{tabular}{|c|c|}
\hline Gerçekleştiren Kurum & Proje ve Konut Adedi \\
\hline Kiptaş Tuzla Konutları 1. & 1332 Sosyal Konut \\
\hline Eiptaş Tuzla Konutları 2.Etap & 1728 Sosyal Konut \\
\hline Kiptaş Tuzla Konutları 3.Etap & 260 Sosyal Konut \\
\hline TOKİ Tuzla 1.Bölge Alt \\
Gelir
\end{tabular}

Kaynak:https://www.toki.gov.tr/ ve http://www.kiptas.istanbul/tr verilerinden düzenlenmiştir.

KiPTAŞ, ürettiği sosyal konutları uzun vadelerde düşük faiz oranlarıyla mortgage sistemiyle kullanıcılarına sunmaktadır. Tuzla'da toplam 3320 adet sosyal konut inşa eden KIPTAŞ, bölgede gerçekleştirdiği projelerle pek çok kişiyi konut sahibi yaparken, aynı zamanda kaçak ve plansız yapılaşmanın önüne geçerek bölgenin planlı şehirleşmesine katkı sağlamıştır. Kiptaş'ın konut üretimi yanında inşa ettiği yeşil alanlar, çocuk oyun alanları, otoparklar, spor alanları ve güvenlik hizmetleri gibi donatılar Tuzla'nın daha modern bir şehir görüntüsüne kavuşmasına da katkı sağlamıştır. Saha çalışmaları esnasında yapılan görüşmelerde bu sosyal donatı alanlarının varlığı kullanıcıları 
tarafindan memnuniyetle değerlendirilmiştir. Kullanıcılar ayrıca bu alanların bakımı için ödedikleri 100 ile 160 TL arasındaki aidatların buna değdiğini de belirtmişlerdir (Tablo 4 ve 5).

Tuzla'da KIPTAŞ dışında Türkiye'nin en büyük konut üretici kuruluşu olan TOKI de sosyal konut üretimi gerçekleştirmiştir. TOKi, yoksul ve dar gelirli gruplara yönelik sosyal konut üretimi çerçevesinde Tuzla Aydınlı Mahallesinde iki sosyal konut projesi hayata geçirmiştir. Bu projelerden biri gecekondu dönüşüm sosyal konut projesi, diğeri ise alt gelirlilere yönelik sosyal konut projesidir. Farklı daire alternatifleriyle toplam 1976 konutun yer aldığı projelerle yoksul ve dar gelirli vatandaşların konut sahibi yapılması amaçlanmıştı. TOKi'nin bu projelerinde vatandaşlar konut bedelinin \%10 ile \%25 arasındaki kısmını peşin olarak ödemiş, geri kalan tutar ise 8 ile 15 yıl arasında değişen vadelere yayılmıştır (TOKi, 2010).

TOKI'nin sosyal konut kapsamında Tuzla'da gerçekleştirmiş olduğu projelerden ilki 760 konutluk Tuzla Birinci Bölge Alt Gelir projesidir. 2006 yılında Aydınlı bölgesinde başlayan proje 2 yıl içerisinde tamamlanmış ve konutlar kura çekimiyle hak sahiplerine teslim edilmiştir. 75 ve $80 \mathrm{~m}^{2}$ büyüklüğünde $2+1$ dairelerden oluşan bu konutlar, 760 YTL'nin altında geliri olanlar, otuz yaşını geçmiş olanlar ve ev sahibi olmayanlar gibi nüfusun dezavantajlı gruplarına öncelik tanınarak satı̧̧a çıkarılmıştır. Proje çerçevesinde konutla birlikte park ve bahçeler, çocuk oyun alanları, spor alanları, çardaklar ve otopark alanlarının inşası da gerçekleştirilmiştir.

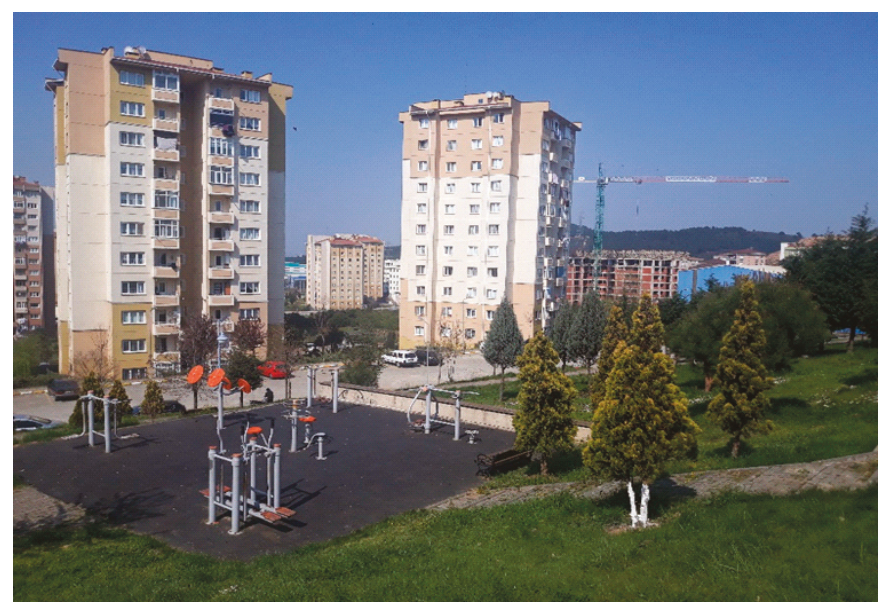

Fotoğraf 2. TOKi Tuzla 2.Etap Sosyal Konutları'ndan bir görünüm Photo 2. View from Tuzla Toki social housing project

TOKI'nin Tuzla'da gerçekleştirmiş olduğu ikinci proje ise Tuzla Aydınlı İkinci Bölge Gecekondu Dönüşüm Projesi'dir. 2008 yıIında tamamlanan bu proje, Tuzla Birinci Bölge Alt Gelir projesiyle aynı bölgede gerçekleştirilmiştir. Proje ile TOKi, eski gecekondu bölgesini yenileyerek, Aydınlı bölgesini çağdaş bir şehirsel görünüme kavuşturmayı hedeflemiştir (Fotoğraf:2). Proje kapsamında gecekondu bölgesinin yakınındaki alanlarda 984 yeni sosyal konut üretilmiş ve gecekondu sahipleri buraya yerleştirmiştir. Eski gecekondu alanlarında ise sosyal donat alanları (cami, okul, otobüs durağı ve park gibi) oluşturulmuştur.

Tuzla'daki bu sosyal konutlarda yaşayanların konut memnuniyetlerini değerlendirmek amacıyla TOKi ve KIPTAŞ konutlarında anket çalışması yapılmıştır. Toplam 100 kişiyle (50'si TOKi, 50’si
Kiptaş kullanıcısı) yapılan anket çalışmasında, katılımcılara konut alanlarının fiziki koşulları ve konut bölgelerindeki sosyal ilişkiler ile ilgili sorular yöneltilmiştir. Sorulara verilen cevaplar Tablo 4 ve 5'te değerlendirilmiştir.

Tablo 4. Konut ve çevresine ait özelliklerin değerlendirilmesi Table 4. Evaluation of the properties of housing and residential environment

\begin{tabular}{|l|l|l|l|l|l|}
\hline Özellikler & $\begin{array}{l}\text { Cok Yeterli } \\
(\mathbf{\%})\end{array}$ & $\begin{array}{l}\text { Yeterli } \\
\mathbf{( \% )}\end{array}$ & $\begin{array}{l}\text { Kararszzım } \\
(\mathbf{\%})\end{array}$ & $\begin{array}{l}\text { Yeterli } \\
\text { Değil (\%) }\end{array}$ & $\begin{array}{l}\text { Hiç Yeterli } \\
\text { Değil (\%) }\end{array}$ \\
\hline $\begin{array}{l}\text { Konut büyüklüğü } \\
\text { yeterli mi? }\end{array}$ & 4 & 35 & 4 & 12 & $\mathbf{4 5}$ \\
\hline $\begin{array}{l}\text { Sosyal alanların } \\
\text { yeterliliği } \\
\text { (Park,Bahçe,Cocu } \\
\text { k oyun alanı) }\end{array}$ & 20 & $\mathbf{6 4}$ & 3 & 10 & 3 \\
\hline Otopark imkânları & 26 & $\mathbf{4 7}$ & 16 & 8 & 3 \\
\hline $\begin{array}{l}\text { Güvenlik } \\
\text { Konutlar mimari ve } \\
\text { estetiksel açıdan } \\
\text { güzeldir }\end{array}$ & 38 & 4 & 5 & $\mathbf{4 5}$ \\
\hline
\end{tabular}

Tablo 4'te görüldüğü gibi kathlımcıların yarısından fazlası ( \%57'si)“konut büyüklüğü" ile ilgili soruya "yeterli değil veya hiç yeterli değil" cevabını vermiştir. Ankete katlanların \%39'u (Kiptaş'ın büyük konutlarında yaşayanlar ile iki kişilik ailelerden oluşan kesim) konut büyüklüğüne "yeterli veya çok yeterli" cevabını vermişlerdir. Katılımcıların \%84'lük büyük kısmı "park, bahçe, yeşil alan ve çocuk oyun alanı" gibi sosyal donatı alanlarının "yeterli veya çok yeterli" olduğunu belirtmiştir. "Otopark imkânları" ile ilgili soruya ise katılımcıların \%73'ü olumlu görüş belirterek "yeterli veya çok yeterli" cevabını vermiştir. \%16 oranında "kararsızım" diyenlerin büyük kısmını ise aracı olmayanlar oluşturmaktadır. Yine ankete katılanların \%77'si, konutlarının "mimari ve estetik" açıdan "yeterli veya çok yeterli" olduğunu belirtmişlerdir. Konut ve çevre özelliklerine ait değerlendirmenin yapıldığı Tablo 4'te dikkat çeken en önemli sonuçlardan biri de konut alanındaki güvenlik sorunlarıdır. Ankete katılanların \% 50'si (hepsi TOKi kullanıcısı) konutlardaki "güvenlik" ile ilgili soruya "yeterli değil veya hiç yeterli değil" cevabını vermiştir. Bölgede Kiptaş'ın inşa ettiği sosyal konut projelerinde güvenlik birimleri yer alırken, TOKi sitelerinde güvenlik birimleri bulunmamaktadır. TOKi sitelerinde yaşayan anket katılımcıları, sitelerinde güvenlik birimlerinin olmamasını sosyal konut projelerinin en olumsuz tarafi olarak belirtmişlerdir (Tablo 4).

Tablo 5. Yerleşim bölgelerindeki sosyal ilişkilerin değerlendirilmesi Table 5. Evaluation of social relations in settlement areas

\begin{tabular}{|c|c|c|c|c|c|}
\hline Özellikler & \begin{tabular}{|l|} 
Kesinlikle \\
Kattllyorum
\end{tabular} & Katıllyorm & Kararsızım & Katılmiyorum & $\begin{array}{l}\text { Hiç } \\
\text { Katılımyorum }\end{array}$ \\
\hline $\begin{array}{l}\text { Sosyal konut } \\
\text { bölgesinde birçok } \\
\text { kisisiyi tanyyorum. }\end{array}$ & 12 & 54 & 18 & 10 & 6 \\
\hline $\begin{array}{l}\text { Konut } \\
\text { bölgesindeki } \\
\text { komșuluk } \\
\text { ilișkilerinden } \\
\text { memnunum. }\end{array}$ & 18 & 55 & 8 & 12 & 7 \\
\hline $\begin{array}{l}\text { Gerekli durumlarda } \\
\text { komșularmmdan } \\
\text { yardim } \\
\text { alabiliyorum }\end{array}$ & 12 & 60 & 14 & 9 & 5 \\
\hline \begin{tabular}{|l} 
Konut bölgesindeki \\
sosyal iliskilerden \\
genel olarak \\
memnunum. \\
\end{tabular} & 9 & 60 & 15 & 7 & 9 \\
\hline $\begin{array}{l}\text { Sosyal konutlarda } \\
\text { yasamaktan } \\
\text { memnun musunuz? }\end{array}$ & 21 & 64 & 8 & 4 & 3 \\
\hline
\end{tabular}

Sosyal konutlarda yaşayanlarla yapılan ankette bu bölgelerdeki, sosyal ilişkilere dair sorular da sorulmuş ve sorulara verilen cevaplar Tablo 5'te değerlendirilmiştir. Ankete katılanların \%66'sı "Konut Yerleşim Alanındaki Birçok Kişiyi Tanıyorum" cevabını verirken, \%16'sı kimseyi tanımadığını belirtmişlerdir. "Komşuluk ilişkilerinden memnunum musunuz" sorusuna ise katlımcıların 
\%73 gibi büyük kısmı "katılıyorum veya kesinlikle katılıyorum" cevabını vererek komşuluk ilişkilerinden memnun olduklarını belirtmişlerdir. Özellikle konut alanlarındaki çardak ve çocuk oyun alanları gibi sosyal donat alanlarının varlığının, kadınlar arasındaki ilişkilerin gelişmesinde etkili olduğu belirtilmiştir. Ayrıca ankete katılanların \% 72'lik büyük bölümü herhangi bir ihtiyaç durumunda komşularının kendilerine yardımcı olabileceğini belirtmişlerdir. Yerleşim alanındaki sosyal ilişkilerle ilgili olarak "konut alanındaki sosyal ilişkilerden memnun musunuz?" sorusuna ise katlımcıların \%69'u "katlıyorum ve kesinlikle katilıyorum" şeklinde olumlu yanıt verirken, $\% 16$ 'sı ise "katılmıyorum veya hiç katılmıyorum" şeklinde yanıt vererek sosyal ilişkilerden duydukları memnuniyetsizliği belirtmişlerdir. Son olarak katilımcılara sorulan "sosyal konutlarda yaşamaktan memnun musunuz?" sorusuna ise katılımcıların \%85'i "katılıyorum veya kesinlikle katlıyorum" cevabını vererek sosyal konutlarda yaşamaktan memnun olduklarını belirtmişlerdir. \%15'i ise "kararsızım, katılmıyorum ve hiç katılmıyorum" cevabını vererek sosyal konutlarda yaşamaktan duygukları memnuniyetsizlikleri belirtmişlerdir.

\section{Tarışma ve Sonuç}

19.yüzyılın başından itibaren sanayileşmenin yarattğı iş olanakları şehirlere olan göçü hızlandırmış, şehirlerde hızla artan nüfus, başta konut olmak üzere pek çok sorunun ortaya çıkmasına neden olmuştur. Bu konut sorununu çözmek amacıyla geliştirilen yöntemlerden biri de sosyal konut uygulamaları olmuştur. 19.yüzyılın sonlarında ilk olarak Batı Avrupa ülkelerinde (İngiltere, Belçika, Fransa ) başlatılan bu uygulamalar, 20. yüzyılın son çeyreğinden itibaren gelişmekte olan ülkelerin de sanayileşme faaliyetlerine katılmalarıyla bu ülkelerde de görülmeye başlanmıştir.

Gelişmekte olan ülkeler kategorisinde yer alan Türkiye'de de sosyal konut uygulamaları ve bağlantılı faaliyetler 1960'lı yıllarda İstanbul ve Ankara gibi büyük şehirlerde başlatılmıştır. Asıl önemli gelişmeler ise 1980 'li yıllarda Toplu Konut İdaresi (TOKi)'nin kurulmasından sonra olmuştur. TOKi, kurulduğu ilk yıllarda konut kooperatiflerine krediler vererek sosyal konut üretimlerinde etkili olurken, 2000'li yıllardan itibaren yetkilerinin daha da arttırılmasıyla konut üretimlerini kendi gerçekleştirme politikalarına ağırlık vermiştir.

İstanbul'da ilk sosyal konut uygulamaları Zeytinburnu, Sağmalcılar (Bayrampaşa) ve Osmaniye Mahallesinde (Bakırköy) gerçekleştirilmiştir (Tekeli, 1996). Daha sonra bu uygulamalar Başakşehir, Küçükçekmece, Pendik ve Tuzla gibi ilçelerde de hayata geçirilmiştir. 2000 sonrası dönemde sosyal konut uygulamalarıyla dikkat çeken Tuzla, 1980'lere kadar kırsal fonksiyonlarıyla ön plana çıkan bir yerleşme idi. 1980 sonrası dönemde ise tersanenin buraya taşınması, organize sanayi bölgelerinin kurulması ve 1990'da TEM Otoyolu'nun bölgeden geçmesi sonrasında İstanbul'un önemli sanayi bölgelerinden biri haline gelmiştir. Sanayi faaliyetlerinin yaratttkları iş olanakları işsiz nüfusu bölgeye çekmiş, bölgede konut yetersizliğinin oluşmasına neden olmuştur. Soruna yetkililerin çözüm üretememeleri, bölgeye gelen nüfusun barınma ihtiyacını kendi olanaklarıyla çözme yoluna gitmelerine neden olmuştur. Böylece iş olanaklarından yararlanmak üzere ilçeye gelen nüfus, sanayi bölgelerinin yakınlarındaki mahallelerde (Aydınlı, Mimar
Sinan ve Şifa ) daha çok hazine arazilerinin işgali şeklinde kendileri için derme çatma konutlar yapmak zorunda kalmışlardır. Bu durum ise Tuzla'da gecekondu mahallelerinin oluşmasına neden olmuştur. Tuzla'daki ilk sosyal konut uygulamaları da bu gecekondu mahallelerini rehabilite etme amacıyla başlatılmıştır (TOKi, 2010). Sonraki yıllarda Tuzla, büyük ölçekli konut uygulamaları için sahip olduğu boş arazileri, makul arsa fiyatları ve güçlü ulaşım altyapısıyla İstanbul'un önemli sosyal konut üretim alanlarından biri haline gelmiştir. Tuzla'nın sahip olduğu bu avantajlar TOKi ve KIPTAŞ gibi kuruluşlar tarafindan değerlendirilmiş ve ilçede TOKI 1744, KIPTAŞ ise 3320 adet sosyal konut inşa etmiştir. Uygulanan sosyal konut projeleriyle bölgede mekânsal bir dönüşüm yaşanmış, belirli plandan yoksun gecekondu bölgeleri yerini nispeten düzenli, yeşil alanlara sahip, konut sitelerine bırakmaya başlamıştır. Ayrıca sosyal konutların etrafinda kısa sürede çeşitli şehirsel fonksiyonların yer almaya başlamasıyla ilçenin gelişimi hız kazanmıştır. Böylece kısa bir süre öncesine kadar tarım alanları ve yeşil alanların varlığıyla dikkat çeken Tuzla'nın mekânsal görünümüne önce sanayi tesisleri, günümüzde ise konut siteleri hâkim olmaya başlamıştır.

Tuzla sahip olduğu ve gelişmeye açık güçlü ulaşım olanakları (D-100 Karayolu, TEM otoyolu ve Marmaray hatt içindeki durakları Aydıntepe, İçmeler, Tuzla), inşası devam eden Tuzla metrosu, makul fiyatlı geniş boş arazileri ve artmaya devam eden nüfusuyla gelecekte de İstanbul'un gözde sosyal konut üretim alanlarından biri olmaya devam edecektir. Kamu yetkililerince Mart 2019 'da yapılan açıklamada, Türkiye genelinde inşa edilecek 50.000 sosyal konutun 6300'ünün İstanbul'da yapılacağı ve bunun 500'ünün Tuzla'da inşa edileceği yönündeki planlamalar (https://www.toki.gov.tr/), Tuzla'nın gelecekte de i̇stanbul'un önemli sosyal konut üretim alanlarından bir olmaya devam edeceğinin bir göstergesidir.

\section{Kaynakça}

Bayraktar, E. (2006) Gecekondu ve Kentsel Yenileme. Ekonomik Araştrmalar Merkezi Yayınları. Ankara.

Bozdoğan, Ö. (2019). İstanbul Anadolu Yakası'ndaki Sosyal Konut Uygulamalarına Coğrafi Bir Bakış: Tuzla Örneği. İstanbul Üniversitesi Sosyal Bilimler Enstitüsü, Yayınlanmamış Yüksek Lisans Tezi, İstanbul.

Çoban, A.N. (2012). Cumhuriyetin İlanından Günümüze Konut Politikası. Ankara Üniversitesi SBF Dergisi, 67 (3), 75-108.

Devlet Planlama Teşkilat 1963. (2016). Birinci beş yıllık kalkınma planı http://www.kalkinma.gov.tr/Lists/Kalknma\%20Planlar/Attachments Son erişim tarihi 10.05.2019.

Doğan, M. (2013). Geçmişten Günümüze İstanbul'da Sanayileşme Süreci ve Son 10 Yıllık Gelişimi. Marmara Coğrafya Dergisi, (27), 511550.

Doğaner, S. (1993). İstanbul'da Gemi İnşa Sanayi Türk Coğrafya Dergisi, (28), 65-116.

Gournay, I. (1993). AlA Guide to the Architecture of Atlanta. (Ed.). G. Sams. Atlanta: University of Georgia Press.

Greenhalgh, S. ve Moss, J (2009). Principles for Social Housing Reform. London: Localis.

Kunduracı, N. F. (2013). Dünyada ve Türkiye'de Sosyal Konut Uygulamaları. Çağdaş Yerel Yönetimler, 22 (3), 53-77.

Malpass, P. ve Murie, A. (1999). Housing Policy and Practice. Basingstoke: Palgrave.

Olgun, H. (2014). Türkiye'de Sosyal Konut Politikası: Seçilmiş Avrupa Ülkeleriyle Karşılaştırmalı Bir Analiz. Gazi Üniversitesi Sosyal Bilimler Enstitüsü, Yayınlanmamış Doktora Tezi Ankara.

Oxley, M. (2009). Financing Affordable Social Housing in Europe. Nai- 
robi: UNHABITAT.

Pacione, M. (2005). Urban Geography-A Global Perspective. London and New York: Routledge.

Pittini, A. ve Laino, E. (2011). Housing Europe Review 2012: The Nuts and Bolts of European Social Housing Systems. Brussels: CECODHAS.

Stone, M. (2003). Social Housing in the UK and US: Evolution, Issues and Prospects. Atlantic Fellow in Public Policy, London.

T.C. 58. Hükümet Acil Eylem Planı (AEP). (2003)http://ekutup.dpt.gov.tr/plan/aep.pdf. Son erişim 24.07.2019.

Tekeli, i.(1996). Türkiye'de Yaşamda ve Yazında Konut Sorununun Gelişimi. Tarih Vakfi Yurt Yayınları. İstanbul.

TOKi. (2010). Türkiye'nin geleceğini inşa ediyoruz. http://i.toki.gov.tr/content/images/main-pageslider/30102016225052-pdf.pdf. Son erişim 16.05.2019

TOKi. (2016). Kurumsal. Geleceğin Türkiye'sini inşa ediyoruz. TOKi.

Tümertekin, E. ve Özgüç, N. (2015). Beşeri Coğrafya. İstanbul: Çantay Kitabevi.

Vroelant, L., C. ve Tutin, C.(2007). Social Housing in France. Social Housing inEurope. (Eds.)C. Whitehead ve K. Scanlon. London: The London Schoolof Economics and Political Science, 70-89.

Wassenberg, F., Vroelant, C. L., ve Reinprecht, C. (2008). Learning from history: changes and path dependency in the social housing sector in Austria, France and the Netherlands (1889-2008). (Eds.) K. ScanIon ve C. Whitehead, Social Housing in Europe II: A Review of Policies and Outcomes (pp. 31-47). The London School of Economics and Political Science. London.

Whitehead, C. ve Scanlon, K. (2007) Social Housing in Europe. Christine Whitehead ve Kathleen Scanlon (ed), Social Housing in Europe, London School of Economics and Political Science, London.

http://www.kiptas.istanbul/tr Son erişim 10 Mayıs 2020. https://www.toki.gov.tr/ Son erişim 10 Mayıs 2020. 